\title{
GENERAL INTRODUCTION: CONSERVING NOVA SCOTIA'S BIODIVERSITY
}

\author{
J.H. MARTIN WILLISON ${ }^{1 *}$ and CHRISTOPHER A. MILLER ${ }^{2}$ \\ ${ }^{1}$ School for Resource \& Environmental Studies, and Biology Department \\ Dalhousie University \\ Halifax, Nova Scotia, B3H 3/5 \\ ${ }^{2}$ Wetlands Research Centre and Department of Biology \\ University of Waterloo \\ Waterloo, Ontario, N2L 3G1
}

\begin{abstract}
The papers on biodiversity in this issue focus on the richness of life in Nova Scotia, and the means by which this richness might be conserved. Mammals, birds, fish, beetles, and diatoms are examples of the richness of life described in the volume. The conservation status of selected species is outlined, as are the threats to these species. Special attention is paid to moose and roseate terns, and a wide range of birds, beetles, fish, mammals and other species receive some attention. Conservation options based on the protection of habitat in Nova Scotia, as well as comprehensive landscape-scale strategies for biodiversity conservation planning, are similarly described both in detail and in general by a variety of authors.
\end{abstract}

Les articles du présent volume portent principalement sur la richesse du vivant en Nouvelle-Écosse et sur les moyens de conserver cette richesse. Mammifères, oiseaux, poissons, coléoptères et diatomées sont au nombre des taxons traités dans le volume. On décrit la situation de certaines espèces et les menaces qui pèsent sur elles. Une attention particulière est accordée à l'orignal et à la Sterne de Dougall, et une grande variété d'oiseaux, de coléoptères, de poissons, de mammifères et d'autres espèces sont également considérées. Plusieurs auteurs décrivent de manière générale ou détaillée des options en matière de conservation fondées sur la protection des habitats en Nouvelle-Écosse ainsi que des stratégies globales à l'échelle des paysages pour la planification de la conservation de la biodiversité.

\section{Introduction}

The Earth is often regarded as being composed of a number of overlapping spheres, such as: lithosphere, hydrosphere, atmosphere, and biosphere. The last of these is the "sphere of life", which is arguably the Earth's most distinctive feature. Over ten million species of multi-cellular life forms are thought to exist, and this number may be matched by the many varieties of microbial life forms (for an introduction, see Gaston \& Spicer 1998). Life forms collectively constitute "biodiversity", which refers to the sum of the richness of life - including genetic diversity (molecular blueprints), organismal diversity (range of taxonomic forms), and ecosystem diversity (living communities, including their abiotic determinants). For a detailed discussion of biodiversity, see E.O. Wilson's 1992 book, The Diversity of Life. A lot of this diversity is, regrettably, threatened by the sheer number of humans inhabiting the planet.

During the most recent 200 years, the human population has increased roughly 6 -fold to about 6.3 billion in 2003 . Not only are humans remarkably numerous, but they are also remarkably consumptive in ecological terms (for a general introduction, see Freedman 1998). Modern humans consume not only food in large quantities, but also large quantities of materials such as fossil fuels and building materials. No other animal is, or ever has been, as consumptive in relation to its size.

\footnotetext{
* Author to whom correspondence should be addressed
} 
Humans are placing considerable stress on Earth's natural systems and processes, which is revealed in many forms of global change, including significant changes in the chemical composition of the atmosphere and the biological composition of the biosphere. These changes cannot continue indefinitely without triggering homeostatic phenomena (see Lovelock 1979). Current human-caused changes in the biosphere are generally described as "biodiversity decline", and "extinction spasm". Although there is no scientific agreement about the rate at which biodiversity is currently declining, there is agreement that it is accelerating (see for examples, Lawton \& May 1995, Soulé 1991). Soulé (1991) considers that we can expect to lose $25-50 \%$ of species diversity in the current human-caused extinction spasm, the precise amount being dependent on how the next 100 years unfolds, and he provides a strategic analysis of the means by which we can apply conservation planning, and thereby keep the losses at the lower end of this range.

In response to the growing stresses on the biosphere caused by expansion of the human enterprise, global and national conservation strategies are being devised by governments and non-government organizations to protect the Earth's resources and biodiversity (for examples, see Munro \& Holdgate 1991, Canadian Biodiversity Strategy 1995). A wide range of conservation strategies, protocols and methods have been developed. These vary from approaches requiring a high degree of technological control that can be applied only in special circumstances, such as with gene banks and zoos, to methods that are elementary and generally applicable, as in the protected areas and community stewardship approaches.

This issue of the Proceedings of the Nova Scotian Institute of Science addresses contemporary matters of biological conservation in Nova Scotia. A lot of conservation research is actively being undertaken within the province, representing a microcosm of the global conservation effort. This issue attempts to assemble a portion of this knowledge. It deals first with the inventory of selected aspects of biodiversity, and then moves on to species-specific conservation issues, and finally to spaces-orientated approaches.

\section{Biodiversity of Nova Scotia}

In order to plan for the conservation of biodiversity in Nova Scotia, it is useful to have access to reliable inventories of species. Detailed lists are currently available for several taxonomic groups within the province, including: plants (Roland and Smith, 1969, Roland 1998), birds (Tufts \& McLaren 1986), herpetofauna (Gilhen 1984), and certain insects (Brunelle 1997, 1999). In other cases, Nova Scotian biologists may turn to lists for nearby regions (for snails and slugs of Maine, for example, see Martin 1999, 2000; for mosses of the Maritime Provinces, see Ireland 1982). As distance from our region increases, however, the general reliability of these records begins to decline. This makes it imperative to develop and maintain detailed lists of biological diversity specific to Nova Scotia.

In this issue of the Proceedings of the Nova Scotian Institute of Science, Fred Scott and Andrew Hebda provide a comprehensive annotated list of mammals occurring within the province. The authors provide information on the taxonomy, distribution, habitat, and conservation status for each of 91 species identified. Both terrestrial and marine mammals are considered. This annotated list will provide a useful framework and standard for a wide range of future ecological studies.

In the next paper, David McCorquodale and Søren Bondrup-Nielsen examine the occurrence and distribution of Cerambycid beetles within Nova Scotia. Cerambycids 
are a family of long-horned beetles with larvae that bore into wood. The authors report the presence of 85 species of Cerambycids in the province, based on a careful and thorough review of museum records. They contrast these findings with the 55 species that are supposed to occur within the province based on reviews of Cerambycid distributions from Canada and North America. This contrast is a powerful reminder that even respected compilations of information on biodiversity can be incomplete or misleading.

In the next paper in this issue, Alison Sherwood and Ronald Deckert report on the diatoms found on rocks in a small stream running out of Williams Lake near Halifax. The authors identify many species not previously reported from the province. In this case, a single small site provided a wealth of records of new species, showing how little we know about the relatively obscure organisms that abound in Nova Scotia.

In the following paper in the issue, Daniel Kehler and co-authors report on the relationship between habitat and beetle diversity in forest stands from central Nova Scotia. Hardwood stands are shown, in general, to possess a greater richness of beetle diversity than softwood stands, with the amount of dead wood biomass being the determining factor in this regard. While the human view of a "healthy forest" might be of one that is full of young and vigorously-growing trees, for beetles a healthy forest is full of decaying wood. Seen through the eyes of a typical beetle (if such can be imagined), the trees are most valuable once they die and begin to decay.

\section{The status of species and habitats}

Rare and endangered species in Canada are examined by a number of committees constituted under national and provincial legislation. The Committee on the Status of Endangered Wildlife in Canada is constituted under the Canada Species At Risk Act, and the Nova Scotia Species at Risk Working Group is constituted under the Nova Scotia Endangered Species Act. These committees must have adequate knowledge to address the conservation needs of species of concern. Information on population trends over several years is required, for example, to distinguish a naturally rare species from one that is undergoing a severe decline in numbers. The status of the former might be classified as being of "special concern", while the latter might be considered "threatened". Four papers in this issue examine the status of select species occurring within the province, and the habitats on which they depend.

Seabirds nest plentifully on the Bird Islands north of Cape Dauphin on Cape Breton Island. Because the Bird Islands provide such important breeding habitat, they have been somewhat protected from human incursions for many years. David McCorquodale and colleagues have pulled together data that demonstrate the population trends of the birds nesting on the islands, and show in their paper that dramatic shifts have occurred over the past 75 years. The population of kittiwakes, for example, has exploded on the islands, while murres and two species of terns have completely disappeared.

In the next paper in this issue, Marty Leonard, Andrew Boyne and Sherman Boates examine the roseate terns of Nova Scotia, with particular focus on the terns of Country Island in Guysborough County. This specific case of an endangered bird species provides some general lessons about conservation planning. The major threats to the terns come from facultative predators, notably gulls, that have become specially numerous as a result of the availability of food that can be scavenged. The authors conclude that the key to maintaining terns is to control the populations of gulls in and around colonies of breeding terns. They show that this can be achieved by non-lethal means. In general terms, this work clearly demonstrates the value of observation, 
experiment, and ongoing monitoring.

One approach to designing effective conservation strategies is to focus on particular species that will provide an "umbrella" for a wide range of other species. In other words, by ensuring that one far-ranging species is adequately protected, many other species with smaller ranges will benefit from the same protection. In Nova Scotia, the moose is a good example of an "umbrella species", because it is very large and therefore needs a lot of habitat. By protecting enough habitat for moose, we can ensure that an adequate amount of space is protected for a variety of other species as well. The moose found on Nova Scotia's mainland are in severe decline and were listed as endangered by Nova Scotia's Department of Natural Resources in 2003. If this decline is due to declining habitat quantity or quality it may be an ominous signal for the health of many other species within the province. In their paper "The distribution, status and habitat associations of moose in mainland Nova Scotia", Tamaini Snaith and Karen Beazley provide a thorough review of the information necessary for ascertaining both the condition of the province's moose and also what might be done to lessen the risk of extirpation.

Special conservation attention needs to be paid to aquatic species because water is especially susceptible to pollution and other insidious threats to biodiversity. In the next paper in this issue, Yoichiro Kanno and John MacMillan examine the fish community of River Philip in Nova Scotia's Cumberland County. The authors develop and test an "index of sustainable coldwater streams" that can be used as a guide for the maintenance of suitable aquatic habitat conditions in other rivers and watersheds in Nova Scotia.

\section{Landscape-scale Conservation Planning}

The last four papers in this issue deal with spaces-orientated approaches to conservation in Nova Scotia. A landscape-level approach is founded upon intimate knowledge of the natural science and biogeography of a defined region, and is arguably the most essential component of a biological conservation plan (see Hummel 1989, Noss \& Cooperrider 1994, Beazley 1997). There are many suitable information sources for landscape-scale conservation planning in Nova Scotia. The layers of rock that provide the foundation of Nova Scotia are described in a beautifully illustrated book of the geology of the region (Atlantic Geoscience Society 2001) and the landscapes themselves have been dissected by Davis \& Browne (1996) in the Natural History of Nova Scotia. Petrie \& Raymond (2002) provide comprehensive information for the Bras d'Or Lakes region of Cape Breton. Conservation planning itself has been examined at the provincial scale in several studies (Ogilvie 1992, Lynds \& Leduc 1995, Beazley 1997, Beazley et al. 2002).

In this issue, Karen Beazley and co-workers examine the potential effects of road density on wildlife, paying special attention to moose populations. The authors show that there is a strong negative correlation between the density of roads within the province and the density of moose. Areas of the province having relatively few roads, for instance, are places most likely to possess remnant pockets of moose. While the availability of suitable habitat also affects the distribution of moose, the researchers found this to be a somewhat less important variable than road density. This work clearly shows the importance of maintaining large roadless wilderness areas as a key component of the province's biodiversity conservation strategy.

In the next paper in this issue, Karen Beazley and co-authors describe the products of a workshop that was held in 1999 to develop a "biodiversity conservation vision" 
for Nova Scotia. The "vision" includes maps showing geographic areas in special need of protection. The results of the workshop emphasize the need for setting aside an adequate amount of land, to ensure that a full spectrum of habitat and landscape diversity occurring within the province is protected. Special emphasis is also placed upon the need for adequate connectivity between protected sites to ensure sufficient genetic exchange among dispersed meta-populations. Lastly, the report also details a vision for the protection of marine biodiversity off the coast of Nova Scotia.

Systems of terrestrial protected areas are rarely planned with the unique considerations of aquatic environments in mind, perhaps because the needs of aquatic systems are not easily addressed in this way. Kanno and Beazley examine this topic in the next paper in this issue by paying attention to specific fish species and fish habitats. The authors conclude that certain species, notably Atlantic Whitefish (Coregonus huntsmani) and BrookTrout (Salvelinus fontinalis), are suitable "focal species" and that watershed-based planning for specific rivers is deserved. The Petite Riviére and River Philip watersheds are selected, in particular, as places in need of special conservation measures, based on the findings of the focal river approach.

In the final paper on biodiversity in this issue, Christopher Miller examines the private land holdings of a forestry company, Stora Port Hawkesbury Ltd., and analyzes the capacity for the company's land holdings to contribute to the wider system of protected areas within Nova Scotia. By using a "coarse-filter" approach, Miller shows that properly selected nature reserves established on some blocks of the company's land could make a strong contribution to nature conservation in the province by filling gaps in the publicly owned network of representative protected areas.

\section{References}

Atlantic Geoscience Society (2001) The last billion years, a geological history of the Maritime Provinces of Canada. Nimbus Publishing, Halifax

Beazley K (1997) Ecological considerations for protected area system design: the need for an integrated approach to maintaining biological diversity. Proc NS Inst Sci 41:59-76

Beazley K, Austin-Smith P Jr, Rader M (2002) Toward completing a protected areas system for Nova Scotia. In: Bondrup-Nielsen S, Munro NWP, Nelson G, Willison JHM, Herman TB, Eagles P (eds) Managing protected areas in a changing world. SAMPAA, Wolfville, NS, p 516-530

Canadian Biodiversity Strategy (1995) Canada's response to the Convention on Biological Diversity. Department of Supply and Services, Ottawa

Freedman B (1998) Environmental science: a Canadian perspective. Prentice-Hall Canada, Scarborough, ON

Davis DS, Browne S (1996) The natural history of Nova Scotia. Nimbus Publishing and Nova Scotia Museum, Halifax

Gaston KJ, Spicer JI (1998) Biodiversity an introduction. Blackwell Science, Oxford

Gilhen J (1984) Amphibians and reptiles of Nova Scotia. Nova Scotia Museum, Halifax

Hummel M (ed) (1989) Endangered spaces, the future for Canada's wilderness. Key Porter Books, Toronto

Ireland RR (1982) Moss flora of the Maritime Provinces. National Museums of Canada, Nat Sci (Ott) Publ Bot 13:1-738

Lawton JH, May RM (eds) (1995) Extinction rates. Oxford University Press, Oxford Lovelock JE (1979) Gaia, a new look at life on earth. Oxford University Press, Oxford 
Lynds JA Leduc JM (1995) Planning for the protection of biodiversity at the landscape level in Nova Scotia. In: Herman TB, Bondrup-Nielsen S, Willison JHM, Munro NWP (eds) Ecosystem monitoring and protected areas. SAMPAA, Wolfville, NS, p 548-558

Martin SM (1999) Freshwater snails (Mollusca: Gastropoda) of Maine. Northeast Nat 6:39-88

Martin SM (2000) Terrestrial snails and slugs (Mollusca: Gastropoda) of Maine. Northeast Nat 7:33-88

Munro DA, Holdgate MW (eds) (1991) Caring for the earth: a strategy for sustainable living. International Union for Conservation of Nature and Natural Resources (IUCN)/ United Nations Environmental Programme (UNEP)/World Wildlife Fund for Nature (WWF), Gland, Switzerland

Noss RF, Cooperrider AY (1994) Saving nature's legacy, protecting and restoring biodiversity. Island Press, Washington, DC

Ogilvie RR (1991) Systems planning for ecological sites in Nova Scotia. In: Willison JHM, Bondrup-Nielsen S, Drysdale C, Herman TB, Munro NWP, Pollock TL (eds) Science and the management of protected areas. Elsevier, Amsterdam, p 145-152

Petrie B, Raymond J (2002) The oceanography of the Bras d'Or Lakes: general introduction. Proc NS Inst Sci 42:1-8

Roland AE (1998) Roland's Flora of Nova Scotia, 3rd edn. Nova Scotia Museum and Nimbus Publishing, Halifax

Roland AE, Smith EC (1969) The Flora of Nova Scotia. Proc NS Inst Sci 26:5-733

Soul ME (1991) Conservation: tactics for a constant crisis. Science (Wash DC) 253:744-750

Tufts RW (1986) Birds of Nova Scotia, 3rd edn. Nimbus Publishing and Nova Scotia Museum, Halifax

Wilson EO (1992) The diversity of life. WW Norton, New York 